\title{
Tyrosine Kinase Inhibition in HPV-related Squamous Cell Carcinoma Reveals Beneficial Expression of cKIT and Src
}

\author{
BENEDIKT KRAMER ${ }^{1}$, MARCEL KNEISSLE ${ }^{1}$, RICHARD BIRK ${ }^{2}$, \\ NICOLE ROTTER ${ }^{1}$ and CHRISTOPH ADERHOLD ${ }^{1}$ \\ ${ }^{1}$ Department of Otorhinolaryngology Head and Neck Surgery, \\ University Hospital Mannheim, Medical Faculty Mannheim, University Heidelberg, Manheim, Germany; \\ ${ }^{2}$ Department of Otorhinolaryngology, Head and Neck Surgery, \\ University Hospital Marburg, University Marburg, Marburg, Germany
}

\begin{abstract}
Background/Aim: Therapeutic options of locally advanced or metastatic head and neck squamous cell carcinoma (HNSCC) are limited. Src and cKIT are key protein regulators for local tumor progression. The aim of the study was to investigate the therapeutic potential of targeted therapies in human squamous cell carcinoma (HNSCC) in vitro. Therefore, the influence of the selective tyrosine kinase inhibitors niotinib, dasatinib, erlotinib, gefitinib and afatinib on Src and cKIT expression in Human papilloma virus (HPV)-positive and HPVnegative squamous cancer cells (SCC) was analyzed in vitro. Materials and Methods: ELISA was performed to evaluate the expression of Src and cKIT under the influence of nilotinib,

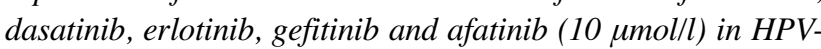
negative and HPV-positive SCC (24-96 $h$ of incubation). Results: Gefitinib significantly increased cKIT expression in $H P V$-positive and HPV-negative cells whereas nilotinib and afatinib decreased cKIT expression in HPV-positive SCC. The influence of tyrosine kinase inhibitors in $H P V$-negative SCC was marginal. Surprisingly, Src expression was significantly increased by all tested tyrosine kinase inhibitors in HPVpositive SCC. Conclusion: The results revealed beneficial and unexpected information concerning the interaction of selective tyrosine kinase inhibitors and the tumor biology of HNSCC.
\end{abstract}

Squamous cell carcinoma of the head and neck (HNSCC) is the most common cancer of the upper aerodigestive tract with an incidence of more than 680,000 new cases every year.

Correspondence to: Benedikt Kramer M.D., Department of Otorhinolaryngology Head and Neck Surgery, University Hospital Mannheim, Theodor-Kutzer-Ufer 1-3, 68167 Mannheim, Germany. Tel: +49 6213831600, Fax: +49 6213833827, e-mail: benedikt. kramer@umm.de

Key Words: cKIT, Src, head and neck squamous cell carcinoma, drug resistance, afatinib, nilotinib, dasatinib, erlotinib, gefitinib.
HNSCC has a mortality rate of approximately 375,000 cases per year (1). Whereas HNSCC is often associated with a continued abuse of alcohol and tobacco, the rising incidence of oropharyngeal HNSCC is HPV-related (2). High-risk type p16 was detected in about $82 \%$ of all HPV-positive HNSCCs (3). It is noteworthy that p16-positive HNSCC shows a better overall survival and 5-year disease-free survival which is highly associated with an improved response to chemo- and radiotherapy (4, 5). HPV-related tumors express viral oncogenes E6 and E7 which are provided by circular viral DNA that encodes two capsid proteins L1 and L2 $(6,7)$. While E7 binds the cullin 2 ubiquitin ligase complex which results in ubiquitination and degradation of the tumor suppressor retinoblastoma protein RB, E6 leads to ubiquitin related proteolysis of p53 and thus causes dysregulation of the cell cycle as well as the loss of p53 conveyed apoptosis $(6,8)$.

CD117, also known as cKIT, is a receptor tyrosine kinase that was discovered in human acute myeloid leukemia (AML) cells $(9,10)$. cKIT is activated by the transmembrane protein stem cell factor (SCF) $(11,12)$. SCF along with cKIT are implicated in various physiologic processes such as embryogenesis and hematopoiesis and play a role in the proliferation and differentiation of stem cells $(9,13,14)$. Various mutations in promoter regions of the cKIT gene lead to malignant transformation of cells through dysregulation of $\operatorname{cKIT}(15,16)$. The dimerization of cKIT activates its tyrosine kinase and results in autophosphorylation $(17,18)$. cKIT leads to the activation of several downstream signaling pathways like phosphatidylinositol-3-kinases (PI3K), Janus kinase/Signal transducer and Activator of Transcription (JAK/STAT), mitogen-activated protein kinase (MAPK) pathways and Src kinases and therefore affects cellular motility, survival and proliferation $(9,16)$. Several mutations of the $c K I T$ protooncogene with a consecutive overexpression of cKIT have been detected in gastrointestinal stromal tumors (GIST) (19). Furthermore, melanomas, ovarian dysgerminomas and HNSCC are associated with either raised cKIT expression levels or mutations of its gene (20-22). 
The cytoplasmic non-receptor tyrosine kinase (nRTK), also known as Src, is a membrane-associated protein, coded by the proto-oncogene $S R C$ (23-25). Src is one of several nRTKs which belong to the Src family kinases (SFK) (25). All SFKs are structurally related, consist of four Src homology ( $\mathrm{SH}$ ) domains and differ in one specific region of the protein (26). Src is normally kept inactive by phosphorylation of tyrosine $530(24,27)$. Src is activated through RTKs such as plateletderived growth factor receptor (PDGFR), epidermal growth factor receptor (EGFR) and cKIT or protein tyrosine phosphatases (PTPs) as PTP1B $(16,27,28)$. SFKs are involved in various signaling cascades like PI3K and MAPK. SFKs can also activate STAT3 which affects cellular survival, differentiation, proliferation and angiogenesis (23). Moreover, the interaction of Src with focal adhesion kinase (FAK), several integrins and the cadherin-catenin complex influences cellular migration, motility, adhesion as well as invasion $(23,24)$.

The dysregulation of several tyrosine kinases was found to influence the development of several oncological diseases (29). Thus, targeted therapies by selective inhibition of tyrosine kinases have been developed for various types of cancers (3032). Up to date, targeted therapies have been introduced in the treatment of HNSCC and are currently under investigation in ongoing clinical Phase III trials (33-35). Afatinib selectively and irreversibly binds EGFR as well as other EGFR kinases such as Her2/neu, Her3 and Her4 (36). In contrast to erlotinib and gefitinib, afatinib binds irreversibly to various EGFR family members and is rather able to escape resistance mechanisms (37). As a result, afatinib has been shown to provide significant clinical benefits in the therapy of non-small cell lung cancer (NSCLC) and is approved in patients with mutated EGFR $(36,38,39)$. Dasatinib targets BCR/ABL as well as cKIT and Src and can be used as a second-line therapy of chronic myeloid leukemia (CML) (40). Erlotinib as well as gefitinib are reversible inhibitors of the tyrosine-kinase domain of EGFR and are used in patients with activating EGFR mutations in NSCLC $(41,42)$. Erlotinib can be also used in patients with metastasized pancreatic carcinoma. Nilotinib targets BCR/ABL, cKIT and PDGFR and can be applied to patients with CML with the philadelphia chromosome or when refractory to conventional treatment options $(43,44)$. This raises the question whether these five tyrosine kinase inhibitors could also be suitable for the therapy of HNSCC. The aim of this study was to investigate the expression of cKIT and Src in HPV negative and positive squamous cell carcinoma (SCC) under the influence of the tyrosine kinase inhibitors nilotinib, dasatinib, erlotinib, gefitinib and afatinib in vitro.

\section{Materials and Methods}

Cell lines, drugs and study design. The HPV negative HNSCC cell lines were kindly provided by T.E. Carey, Ph.D. University of Michigan, Ann Arbor, MI, USA. HNSCC 11A cell line originated from a primary squamous cell carcinoma of the epiglottis, whereas HNSCC
14C originated from a skin metastasis of an oral SCC after radiation, chemotherapy and surgery. The CERV196 cell line is positive for HPV 16 and was provided from poorly differentiated SCC of the uterine cervix and acquired from Cell Lines Service GmbH, Eppelheim, Germany. HPV negative cells were cultured with Eagle's minimum essential medium (Gibco, Life Technologies, Carlsbad, CA, USA) and supplemented with $2 \mathrm{mM}$ of L-glutamine, $10 \%$ fetal calf serum and Pen-Strep (Gibco, Life Technologies). Cultured HPV positive cells were supplemented with $2 \mathrm{mM}$ L-glutamine, $1.0 \mathrm{~g} / 1$ sodium bicarbonate, $1.0 \mathrm{~g} / 1$ sodium pyruvate, $0.1 \mathrm{mM}$ non-essential aminoacids and $10 \%$ of fetal bovine serum (Gibco, Life Technologies). Cell cultures were grown under standardized conditions $\left(37^{\circ} \mathrm{C}, 5 \% \mathrm{CO}_{2}\right.$, $95 \%$ humidity). For subcultures $0.05 \%$ trypsin/0.02\% EDTA solution was added for 5 minutes at $37^{\circ} \mathrm{C}$ (Sigma Aldrich, St. Louis, MO, USA). Incubation time ranged from 24 to $96 \mathrm{~h}$. Nilotinib, dasatinib, gefitinib, erlotinib and afatinib were provided by the Oncological Department, University Hospital Mannheim GmbH. Substances were dissolved in dimethylsulfoxide at a concentration of $10 \mu \mathrm{mol} / \mathrm{l}$. Cell proliferation assay was performed in 96-well microtiter plates (alamarBlue $^{\odot}$, AbD Serotec, Oxford, UK).

Enzyme-linked immunosorbent assay (ELISA) for cKIT and Src. To determine the protein concentrations of cKIT and Src sandwich ELISA technique was applied. For both proteins, DuoSet ELISA development kits (R\&D Systems, Inc., Minneapolis, MN, USA and Bio-Techne GmbH, Wiesbaden, Germany) were used (DY332 for cKIT and DYC2685 for Src) and performed in accordance to the manufacturer's instructions. The optical density was measured at a wavelength of $450 \mathrm{~nm}$ with wavelength correction set to $540 \mathrm{~nm}$ with a MRX Microplate Reader (DYNEX Technologies, Chantilly, VA, USA). Concentrations were determined in $\mathrm{pg} / \mathrm{ml}$ and the detection range was $31.2-2000 \mathrm{pg} / \mathrm{ml}$ for cKIT and 3.91-250 pg/ml for Src. The inter-assay coefficient of variation reported by the manufacturer was $<10 \%$.

Statistical analysis. The statistical analysis was performed using the mean values for each experiment. Each experiment was independently performed for three $(n=3)$ times. The means were compared to the mean values of the negative control using the twocoefficient variance test to assess statistical significance (SAS Statistics software, version 9.3; SAS Institute, Inc., Cary, NC, USA). The resulting $p$-values were adjusted by using Dunnett's test. For all analyses, a $p$-value $\leq 0.05$ was defined as statistically significant. The statistical analysis was performed in collaboration with Prof. Dr. C. Weiss, Institute of Biomathematics, Medical Faculty Mannheim, University of Heidelberg, Germany.

\section{Results}

cKIT expression in HNSCC 11A, 14C and CERV196. cKIT expression was observed in all three cell lines tested, reaching the highest expression levels in HPV positive CERV196 after $96 \mathrm{~h}$. All tested substances led to an alteration of cKIT expression. In CERV196, the expression of cKIT increased in a time-dependent manner in both, untreated cultures and after treatment with tyrosine kinase inhibitors. One exception can be stated after treatment with gefitinib as cKIT expression after $48 \mathrm{~h}$ was slightly reduced compared to $24 \mathrm{~h}$. However, after $48 \mathrm{~h}$ of incubation, cKIT expression was significantly 
Table I. cKIT expression in HPV-negative HNSCC 11A and 14C and HPV-positive CERV196 after incubation with gefitinib, erlotinib, dasatinib, nilotinib, and afatinib (10 $\mu \mathrm{mol} / \mathrm{l})$. Data are mean values $[\mathrm{pg} / \mathrm{ml}]$.

\begin{tabular}{|c|c|c|c|c|c|c|c|c|c|c|c|}
\hline \multirow[t]{2}{*}{$\begin{array}{l}\text { Incubation } \\
\text { time (h) }\end{array}$} & \multirow{2}{*}{$\begin{array}{c}\begin{array}{c}\text { Negative } \\
\text { control }\end{array} \\
\text { Mean }\end{array}$} & \multicolumn{2}{|c|}{$\begin{array}{l}\text { Gefitinib } \\
(10 \mu \mathrm{mol} / \mathrm{l})\end{array}$} & \multicolumn{2}{|c|}{$\begin{array}{l}\text { Erlotinib } \\
(10 \mu \mathrm{mol} / \mathrm{l})\end{array}$} & \multicolumn{2}{|c|}{$\begin{array}{l}\text { Dasatinib } \\
(10 \mu \mathrm{mol} / \mathrm{l})\end{array}$} & \multicolumn{2}{|c|}{$\begin{array}{l}\text { Nilotinib } \\
(10 \mu \mathrm{mol} / \mathrm{l})\end{array}$} & \multicolumn{2}{|c|}{$\begin{array}{c}\text { Afatinib } \\
(10 \mu \mathrm{mol} / 1)\end{array}$} \\
\hline & & Mean & $p$-Value & Mean & $p$-Value & Mean & $p$-Value & Mean & $p$-Value & Mean & $p$-Value \\
\hline \multicolumn{12}{|c|}{ HNSCC 11A } \\
\hline $24 \mathrm{~h}$ & 15.53 & 18.47 & 0.466 & 17.77 & 0.026 & 18.17 & 0.093 & 16.27 & 0.837 & 15.37 & 0.969 \\
\hline $48 \mathrm{~h}$ & 14.60 & 19.30 & 0.015 & 13.07 & 0.683 & 17.20 & 0.440 & 15.47 & 0.849 & 19.17 & 0.020 \\
\hline $72 \mathrm{~h}$ & 18.90 & 24.00 & 0.664 & 15.50 & 0.029 & 18.57 & 0.982 & 20.87 & 0.048 & 14.33 & 0.005 \\
\hline $96 \mathrm{~h}$ & 15.40 & 19.60 & 0.003 & 19.50 & 0.006 & 15.73 & 0.962 & 14.60 & 0.453 & 17.37 & 0.397 \\
\hline \multicolumn{12}{|c|}{ HNSCC $14 \mathrm{C}$} \\
\hline $24 \mathrm{~h}$ & 14.30 & 18.07 & 0.052 & 14.10 & 0.994 & 12.73 & 0.188 & 13.70 & 0.812 & 11.87 & 0.154 \\
\hline $48 \mathrm{~h}$ & 16.33 & 16.20 & 0.999 & 17.07 & 0.816 & 17.10 & 0.934 & 16.13 & 0.992 & 13.63 & 0.299 \\
\hline $72 \mathrm{~h}$ & 15.23 & 18.30 & 0.008 & 14.67 & 0.731 & 14.53 & 0.701 & 13.80 & 0.300 & 14.50 & 0.910 \\
\hline $96 \mathrm{~h}$ & 15.50 & 14.60 & 0.875 & 14.30 & 0.758 & 17.00 & 0.487 & 16.23 & 0.928 & 14.33 & 0.765 \\
\hline \multicolumn{12}{|l|}{ CERV196 } \\
\hline $24 \mathrm{~h}$ & 12.13 & 19.43 & 0.008 & 16.70 & 0.077 & 17.63 & 0.003 & 13.60 & 0.387 & 13.77 & 0.700 \\
\hline $48 \mathrm{~h}$ & 17.30 & 19.33 & 0.632 & 18.53 & 0.689 & 18.37 & 0.370 & 14.30 & 0.385 & 19.00 & 0.086 \\
\hline $72 \mathrm{~h}$ & 33.33 & 41.97 & 0.008 & 29.97 & 0.194 & 34.47 & 0.940 & 25.63 & $<0.001$ & 21.97 & $<0.001$ \\
\hline $96 \mathrm{~h}$ & 43.53 & 66.53 & $<0.001$ & 34.60 & 0.018 & 42.57 & 0.580 & 29.57 & $<0.001$ & 28.43 & $<0.001$ \\
\hline
\end{tabular}

Statistically significant differences $(\mathrm{p} \leq 0.05)$ in bold.

elevated compared to the negative control $(p=0.008)$. Gefitinib led to an increased cKIT expression in all three cell lines with a statistically significant increase after $48(p=0.015)$ and 96 $(p=0.003) \mathrm{h}$ in HNSCC 11A, after $72(p=0.008) \mathrm{h}$ in HNSCC $14 \mathrm{C}$ and after $24(p=0.008), 72(p=0.008)$ and $96 \mathrm{~h}(p<0.001)$ in HPV-positive CERV196. Erlotinib significantly altered cKIT expression only in HNSCC 11A and CERV196. In CERV196 the expression was significantly decreased after 96 $(p=0.018) \mathrm{h}$, whereas a statistically significant decrease of cKIT levels in HNSCC 11A were only observed after 72 $(p=0.029)$ h. Surprisingly, erlotinib led to a statistically significant increase in cKIT after $24(p=0.026)$ and 96 $(p=0.006) \mathrm{h}$. The expression pattern of cKIT in erlotinib treated cells in HNSCC $14 \mathrm{C}$ was similar to those of the negative control of HNSCC 14C. The influence of dasatinib on cKIT expression in all tested cell lines was negligible with one exception in CERV196 after $24 \mathrm{~h}$ when cKIT expression was significantly elevated compared to the negative control $(p=0.003)$. Nilotinib revealed interesting results regarding cKIT expression. Whereas nilotinib significantly increased cKIT expression in HPV negative HNSCC $11 \mathrm{~A}$ after 72 $(p=0.048) \mathrm{h}$, a significant decrease in cKIT expression in HPV positive CERV 196 was observed after $72(p<0.001)$ and 96 $(p<0.001)$ h. A statistically significant decrease in cKIT expression was also observed after treatment with afatinib in CERV196 after $72(p<0.001)$ and $96(p<0.001) \mathrm{h}$, whereas the expression of cKIT was decreased after $72(p=0.005)$ in HNSCC 11A, however increased after $48(p=0.02) \mathrm{h}$. Interestingly, in HNSCC $14 \mathrm{C}$, a significant effect on cKIT expression was only seen after gefitinib treatment. It is noteworthy that gefitinib was the only substance that increased the expression of cKIT independent of the HPV status. Data are displayed in Table I and Figure 1.

Src expression in HNSCC 11A, 14C and CERV196. SRC expression was observed in all three cell lines tested. In the negative control of HPV negative HSNCC 11A cells the expression of Src increased time-dependently whereas fluctuating levels of Src were detected in the other tested cell lines. With one exception after treatment with gefitinib, the expression of Src increased statistically significantly after exposition to all tested substances in HNSCC 11A $(p \leq 0.036)$. This effect was observed after $24 \mathrm{~h}$ of treatment $(p \leq 0.007)$. Gefitinib had no significant effect on Src expression in the HPV negative HNSCC 11A. However, in HPV negative HNSCC 14C gefitinib led to a significant reduction in Src levels after $96 \mathrm{~h}(p=0.009)$. In HPV-positive CERV196, gefitinib significantly increased Src expression after 24 $(p<0.001)$ and $96 \mathrm{~h}(p=0.005)$. It is noteworthy, that this gefitinib-induced increase after $24 \mathrm{~h}$ marks the highest level of Src expression in CERV196. Erlotinib increased Src levels only after $24 \mathrm{~h}$ in HNSCC $11 \mathrm{~A}(p=0.003)$ and in HPV positive CERV196 $(p=0.008)$. In HPV negative HNSCC $14 \mathrm{C}$, erlotinib had no significant impact on Src expression. In HPV negative HNSCC $11 \mathrm{~A}$, dasatinib led to a statistically significant increase after 24 and $48 \mathrm{~h} \quad(p=0.002$ and $p=0.036$ ). It is noteworthy that dasatinib was the only tested substance that caused a decrease in Src expression in 

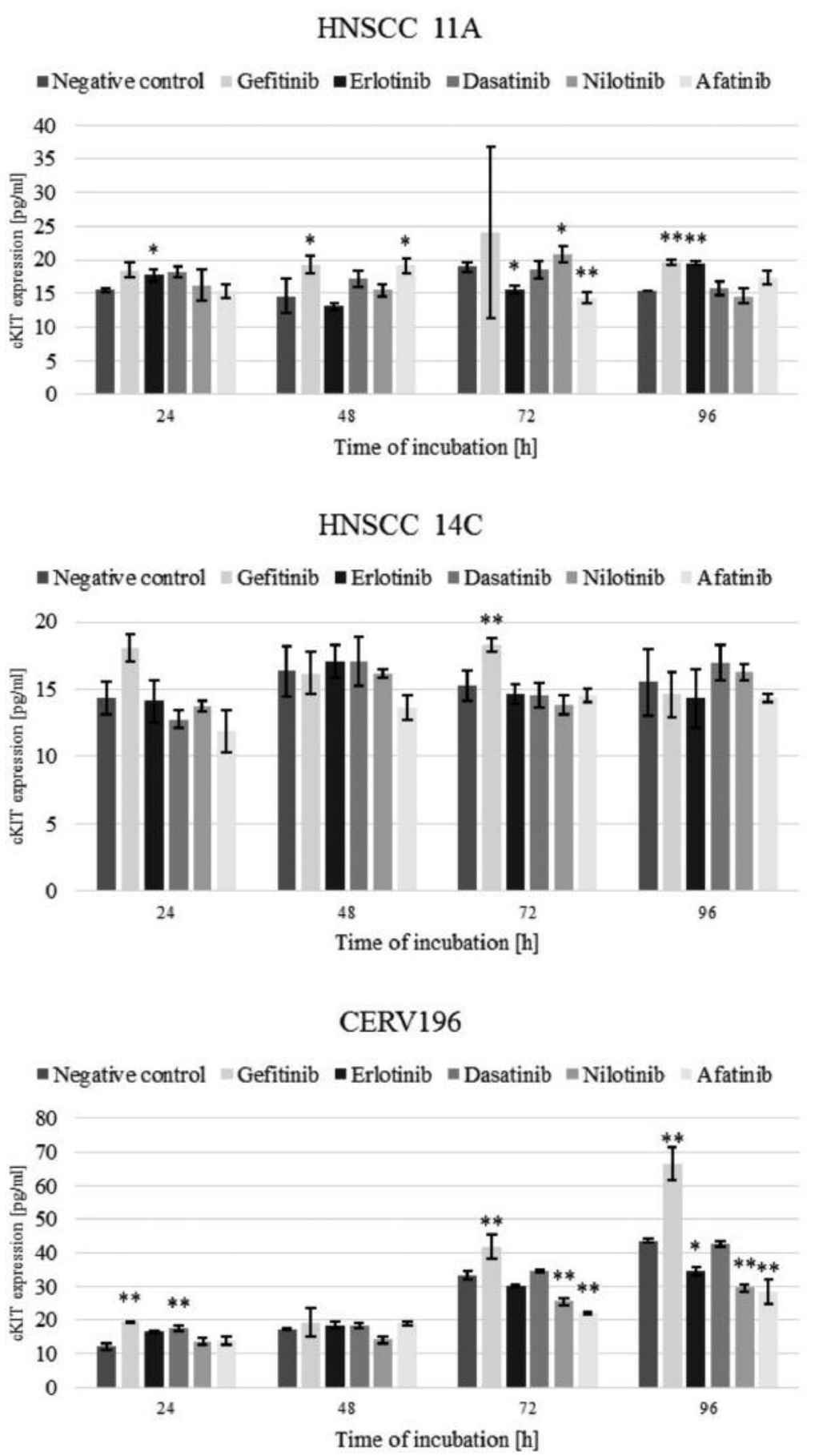

Figure 1. cKIT expression in HNSCC 11A, 14C and CERV196 after incubation with gefitinib, erlotinib, dasatinib, nilotinib, and afatinib at $10 \mu$ mol/l compared to the negative control. Data are mean values. Standard deviation is indicated $(* p<0.05, * * p<0.01)$.

HNSCC $11 \mathrm{~A}$ after $96 \mathrm{~h}(p=0.002)$. Dasatinib had no significant impact on Src expression in HNSCC 14C but caused a significant increase in Src after $24 \mathrm{~h}$ in HPV positive CERV196 ( $p=0.043$ ). Nilotinib led to a significant increase in Src only after $24 \mathrm{~h}$ in $\operatorname{HNSCC} 11 \mathrm{~A}(p=0.002)$ and after $96 \mathrm{~h}$ in the CERV $196(p=0.01)$. Nilotinib was the only tested drug that showed no effect in the CERV196 after 24 h. Src expression in HNSCC 14C was not affected by nilotinib compared to erlotinib and dasatinib. Afatinib influenced Src expression in all tested cell lines. It caused a 
Table II. Src expression in HPV-negative HNSCC 11A and $14 C$ and HPV-positive CERV196 after incubation with gefitinib, erlotinib, dasatinib, nilotinib, and afatinib (10 $\mu \mathrm{mol} / \mathrm{l})$. Data are mean values $[\mathrm{pg} / \mathrm{ml}]$.

\begin{tabular}{|c|c|c|c|c|c|c|c|c|c|c|c|}
\hline \multirow[t]{2}{*}{$\begin{array}{l}\text { Incubation } \\
\text { time (h) }\end{array}$} & \multirow{2}{*}{$\begin{array}{c}\begin{array}{c}\text { Negative } \\
\text { control }\end{array} \\
\text { Mean }\end{array}$} & \multicolumn{2}{|c|}{$\begin{array}{l}\text { Gefitinib } \\
(10 \mu \mathrm{mol} / \mathrm{l})\end{array}$} & \multicolumn{2}{|c|}{$\begin{array}{l}\text { Erlotinib } \\
(10 \mu \mathrm{mol} / \mathrm{l})\end{array}$} & \multicolumn{2}{|c|}{$\begin{array}{l}\text { Dasatinib } \\
(10 \mu \mathrm{mol} / \mathrm{l})\end{array}$} & \multicolumn{2}{|c|}{$\begin{array}{l}\text { Nilotinib } \\
(10 \mu \mathrm{mol} / \mathrm{l})\end{array}$} & \multicolumn{2}{|c|}{$\begin{array}{l}\text { Afatinib } \\
(10 \mu \mathrm{mol} / \mathrm{l})\end{array}$} \\
\hline & & Mean & $p$-Value & Mean & $p$-Value & Mean & $p$-Value & Mean & $p$-Value & Mean & $p$-Value \\
\hline \multicolumn{12}{|c|}{ HNSCC 11A } \\
\hline $24 \mathrm{~h}$ & 11.40 & 27.13 & 0.063 & 37.60 & 0.003 & 29.07 & 0.002 & 27.23 & 0.002 & 26.30 & 0.007 \\
\hline $48 \mathrm{~h}$ & 13.30 & 12.07 & 0.961 & 19.93 & 0.613 & 26.43 & 0.036 & 15.73 & 0.813 & 29.53 & $<0.001$ \\
\hline $72 \mathrm{~h}$ & 27.43 & 22.83 & 0.733 & 15.87 & 0.175 & 25.10 & 0.797 & 30.73 & 0.142 & 19.17 & 0.088 \\
\hline $96 \mathrm{~h}$ & 34.47 & 30.97 & 0.553 & 30.73 & 0.754 & 9.07 & 0.002 & 12.07 & 0.114 & 38.67 & 0.811 \\
\hline \multicolumn{12}{|c|}{ HNSCC $14 \mathrm{C}$} \\
\hline $24 \mathrm{~h}$ & 27.60 & 18.93 & 0.766 & 28.30 & 1.000 & 28.47 & 0.999 & 29.87 & 0.990 & 20.87 & 0.695 \\
\hline $48 \mathrm{~h}$ & 25.43 & 25.40 & 1.000 & 30.27 & 0.551 & 32.10 & 0.255 & 25.53 & 1.000 & 23.47 & 0.926 \\
\hline $72 \mathrm{~h}$ & 24.60 & 26.53 & 0.910 & 26.83 & 0.940 & 30.77 & 0.142 & 22.00 & 0.527 & 27.83 & 0.367 \\
\hline $96 \mathrm{~h}$ & 34.90 & 17.07 & 0.009 & 24.13 & 0.277 & 32.70 & 0.901 & 34.80 & 1.000 & 24.70 & 0.030 \\
\hline \multicolumn{12}{|l|}{ CERV196 } \\
\hline $24 \mathrm{~h}$ & 16.10 & 36.60 & $<0.001$ & 29.57 & 0.008 & 23.10 & 0.043 & 25.33 & 0.367 & 29.00 & 0.033 \\
\hline $48 \mathrm{~h}$ & 20.63 & 19.43 & 0.992 & 26.10 & 0.526 & 11.47 & 0.174 & 17.40 & 0.820 & 16.00 & 0.313 \\
\hline $72 \mathrm{~h}$ & 28.27 & 21.93 & 0.498 & 29.50 & 0.994 & 32.27 & 0.457 & 32.60 & 0.465 & 21.87 & 0.348 \\
\hline $96 \mathrm{~h}$ & 19.07 & 28.57 & 0.005 & 20.00 & 0.994 & 18.00 & 0.992 & 31.03 & 0.010 & 30.93 & 0.005 \\
\hline
\end{tabular}

Statistically significant differences $(\mathrm{p} \leq 0.05)$ in bold.

significant increase in Src expression in HPV negative HNSCC 11A and HPV positive CERV196; in HNSCC 11A after 24 and $48 \mathrm{~h}(p=0.007$ and $p<0.001)$ and in CERV196 after 24 and $96 \mathrm{~h}(p=0.033$ and $p=0.005)$. In HNSCC $14 \mathrm{C}$ afatinib led to a significant reduction in Src after $96 \mathrm{~h}$ $(p=0.03)$. Data are displayed in Table II and Figure 2.

\section{Discussion}

This study was designed to investigate the expression of cKIT and Src in HPV positive and HPV negative SCC after treatment with the tyrosine kinase inhibitors gefitinib, erlotinib, dasatinib, nilotinib and afatinib. cKIT and Src play a role in local tumor progression and are key regulators of cell motility and survival $(9,23)$. Targeted therapy is established in several cancer entities and the evaluation on SCC protein expression patterns may give essential insights into the cellular signaling in HNSCC as well as possible new strategies to alternative therapeutic approaches (30-32).

cKIT expression was observed in all tested cell lines and the highest expression levels were found in HPV positive CERV196. This observation is interesting as it suggests an even stronger elevation of cKIT expression in HPV positive SCC compared to increased cKIT expression in HPV negative HNSCC (20). Furthermore, it indicates an increased activity of cKIT related signaling pathways in HPV positive SCC. Thus, our results are in accordance with the findings of de Melo Maia et al. who stated that vulvar tumors with high cKIT expression levels are associated with a better prognosis
(45). One possible explanation may therefore include an elevated cKIT expression in HPV positive tumors. For all tested cell lines, a statistically significant effect of TKI treatment was detected regarding cKIT expression. However, in HPV negative HNSCC $14 \mathrm{C}$ an alteration in cKIT expression was only observed after treatment with gefitinib for $72 \mathrm{~h}$. In contrast to this observation, cKIT expression in HNSCC 11A has been variously alternated by all tested TKI despite dasatinib. A possible explanation is that HNSCC 14C is originated from metastatic tissue and might be less susceptible to tyrosine kinase inhibition than HNSCC 11A cells which are derived from a primary epiglottis SCC due to mutations in the target protein. This might also explain why both TKI dasatinib and nilotinib, which act as direct cKIT inhibitors, have limited effects in HNSCC 14C regarding cKIT expression $(40,43)$. However, cKIT expression in HNSCC 11A was not significantly affected by dasatinib as in HPV positive CERV196. This indicates that HPV related SCC could be rather sensitive to TKI inhibition compared to HPV negative SCC. Another explanation for this observation is that CERV196 was the only tested cell line which led to a significant alteration in cKIT after treatment with all applied TKI. This is relevant as cKIT inhibition facilitates a decreased tumor growth as well as increased cell survival in several tumor entities $(19,46)$.

The non-receptor tyrosine kinase Src is normally kept inactive but can be activated through RTKs like EGFR or PDGFR. Once activated, Src can interact with various RTKs, FAKs and other cellular regulators (47). Src is, 
HNSCC $11 \mathrm{~A}$

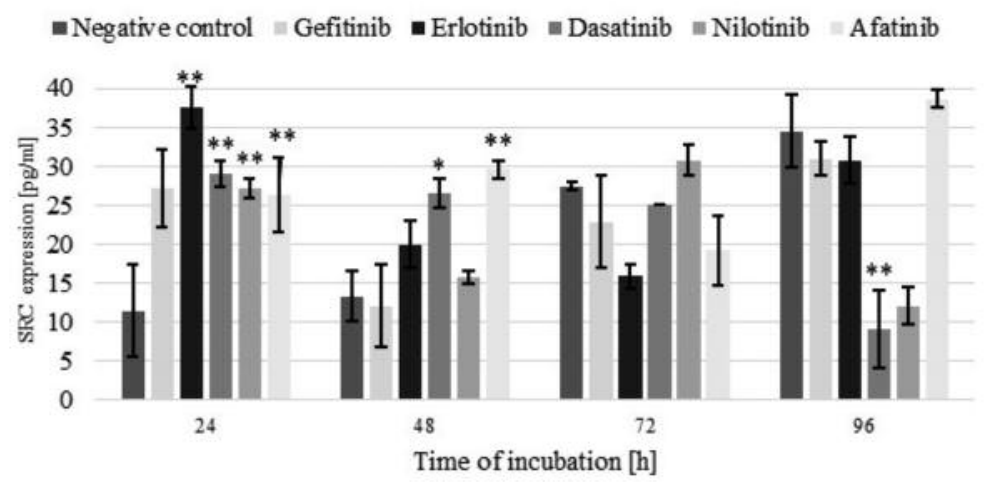

HNSCC $14 \mathrm{C}$
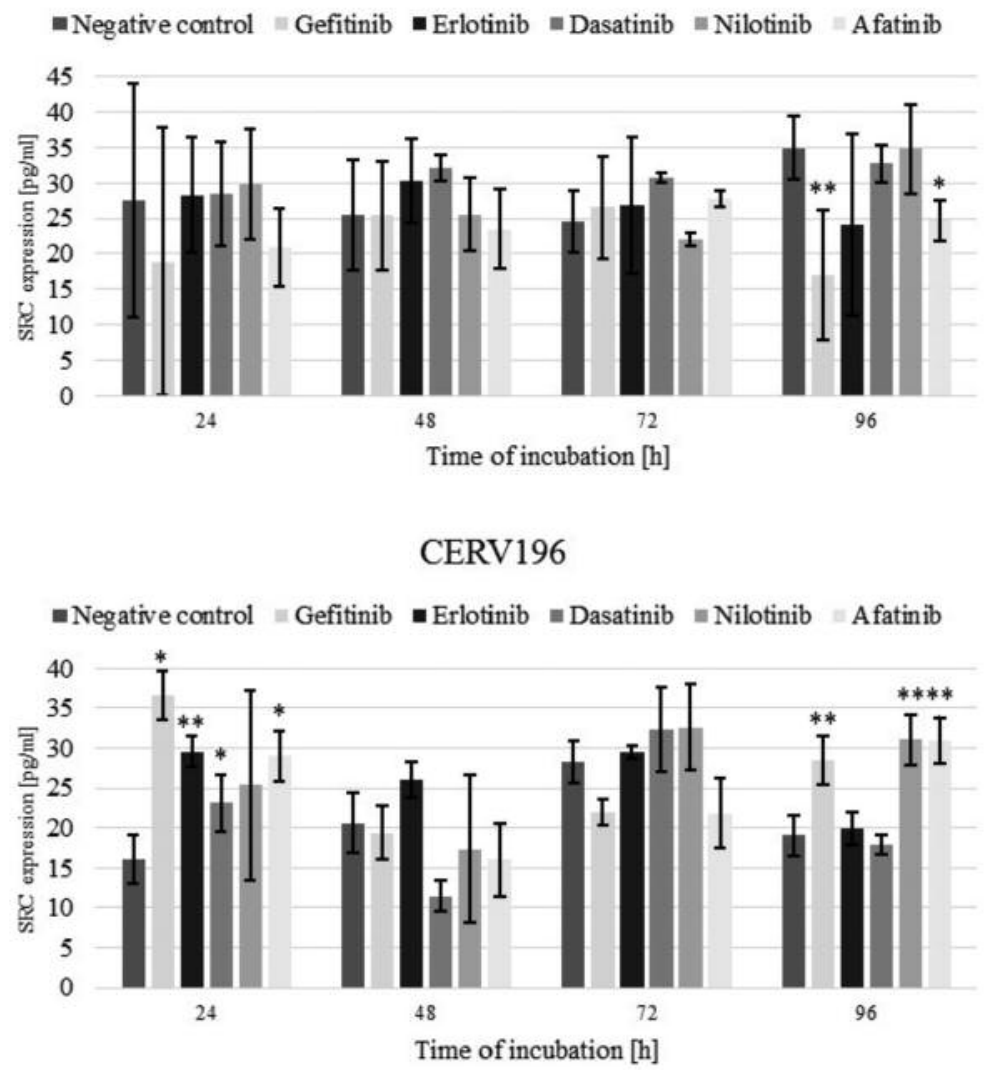

Figure 2. Src expression in HNSCC 11A, 14C and CERV196 after incubation with gefitinib, erlotinib, dasatinib, nilotinib, and afatinib at 10 umol/l compared to the negative control. Data are mean values. Standard deviation is indicated $(* p<0.05, * * p<0.01)$.

therefore, involved in cellular migration, motility, adhesion and invasion $(23,24)$. As already published in previous works, protein expression can be substantially influenced by selective TKIs in HPV related SCC (48-51). Src expression could be observed in all tested cell lines but not all tested TKIs showed an effect on Src expression. In HPV negative HNSCC 11A, all tested substances except of gefitinib led to a significant alteration in Src expression. Yet, only erlotinib which is structurally related to gefitinib significantly increased Src expression after $24 \mathrm{~h}(41,42)$. These findings are surprising as Src acts downstream of EGFR and can be activated through this receptor tyrosine kinase (52). This is possible due to the fact that Src is not affected by selective EGFR inhibition in HPV negative HNSCC. Distinct effects 
on Src expression were not observed after treatment with erlotinib as well as gefitinib in HNSCC 14C and HPV positive CERV196. Only gefitinib significantly decreased Src expression in HNSCC $14 \mathrm{C}$ after $96 \mathrm{~h}$. This leads to the question whether selective EGFR inhibiting proteins can induce drug resistance in HNSCC through potential predictive biomarkers. Stabile et al. demonstrated that Src activation is an indicator of erlotinib resistance in HNSCC (53). These observations can be interpreted as another indication for the assumption why HNSCC $14 \mathrm{C}$ cells are less responsive to tyrosine kinase inhibition. Concerning dasatinib as a direct Src inhibitor, the expression of Src in HNSCC 11A increased after 24 and $48 \mathrm{~h}$ but then decreased significantly after $96 \mathrm{~h}$ (40). This is notable, since no other combination of cell line and treatment has led to both, an increase and a decrease in Src expression levels. Dasatinib may act as a direct inhibitor of Src particularly in HPV negative HNSCC 11A cells, as they originate from primary epiglottis SCC. Yet, it remains unclear how HNSCC 14C and HPV positive CERV196 cancer cells react to dasatinib treatment. It has been demonstrated that acquired EGFR resistance is responsible for the refractory behavior of squamous cancer cells to EGFR inhibiting substances (54). This may be why Src as a downstream effector of EGFR, could be difficult to target. However, it has been shown that Src family kinases are activated in cetuximab-resistant cells that could be resensitized to cetuximab by using dasatinib (55). Another option would therefore be a combination of Src inhibition and selective EGFR inhibition (56). Moreover, the activation of EGFR might be a regulator of dasatinib mediated effects. Increasing levels of activated EGFR could prevent dasatinib-mediated apoptosis through Src (57). Regarding HPV positive CERV196, all tested TKIs led to a significant alteration in Src expression. As previously suggested, HPV-positive tumors might be more responsive to selective tyrosine kinase inhibitors compared to HPV-negative SCC. However, it is remarkable that the expression of Src was significantly increased by the TKIs. A possible explanation for the increased Src expression in HPV-positive cancer cells could be the yet undetected evasive mechanisms of these cells through oncogenic proteins such as E6 and E7 or through HPV-related autocrine release of cell stabilizing proteins that prevent apoptosis (58). Finally, yet unknown mechanisms of drug resistance could affect chemosensitivity in HPV related squamous cancer (59).

To our knowledge, this is the first study investigating the influence of gefitinib, erlotinib, dasatinib, nilotinib and afatinib on the expression patterns of cKIT and Src in HPV positive and HPV negative SCC in vitro. Significant changes in cKIT and Src expression after treatment with these tyrosine kinase inhibitors in both, HPV negative and HPV positive SCC were detected. In addition, the results provide novel aspects in the interaction of cKIT and Src with small molecule tyrosine kinase inhibitors in HNSCC in vitro. The results also reveal possible innovative approaches for further investigations of potential new strategies in targeted therapy of HNSCC.

\section{Acknowledgements}

The Authors thank Petra Prohaska, Mannheim, Germany, for technical support and Prof. Dr. C. Weiss, Institute of Biomathematics, Medical Faculty Mannheim, University of Heidelberg, Germany, for advice in statistical analysis.

\section{References}

1 Ferlay J, Soerjomataram I, Dikshit R, Eser S, Mathers C, Rebelo M, Parkin DM, Forman D and Bray F: Cancer incidence and mortality worldwide: Sources, methods and major patterns in globocan 2012. Int J Cancer 136(5): E359-386, 2015.

2 Hussein AA, Helder MN, de Visscher JG, Leemans CR, Braakhuis BJ, de Vet HCW and Forouzanfar T: Global incidence of oral and oropharynx cancer in patients younger than 45 years versus older patients: A systematic review. Eur J Cancer 82: 115127, 2017.

3 Ndiaye C, Mena M, Alemany L, Arbyn M, Castellsagué X, Laporte L, Bosch FX, de Sanjosé S and Trottier H: Hpv DNA, e6/e7 mrna, and p16ink4a detection in head and neck cancers: A systematic review and meta-analysis. Lancet Oncol 15(12): 1319-1331, 2014.

4 Coordes A, Lenz K, Qian X, Lenarz M, Kaufmann AM and Albers AE: Meta-analysis of survival in patients with hnscc discriminates risk depending on combined hpv and p16 status. Eur Arch Otorhinolaryngol 273(8): 2157-2169, 2016.

5 Sturgis EM and Ang KK: The epidemic of hpv-associated oropharyngeal cancer is here: Is it time to change our treatment paradigms? J Natl Compr Canc Netw 9(6): 665-673, 2011.

6 Dok R and Nuyts S: Hpv positive head and neck cancers: Molecular pathogenesis and evolving treatment strategies. Cancers (Basel) 8(4), 2016. doi: 10.3390/cancers8040041. [Epub ahead of print].

7 Conway MJ, Alam S, Ryndock EJ, Cruz L, Christensen ND, Roden RBS and Meyers C: Tissue-spanning redox gradientdependent assembly of native human papillomavirus type 16 virions. J Virol 83(20): 10515-10526, 2009.

8 Scheffner M, Werness BA, Huibregtse JM, Levine AJ and Howley PM: The e6 oncoprotein encoded by human papillomavirus types 16 and 18 promotes the degradation of $\mathrm{p} 53$. Cell 63(6): 1129-1136, 1990.

9 Pittoni P, Piconese S, Tripodo C and Colombo MP: Tumorintrinsic and -extrinsic roles of c-kit: Mast cells as the primary off-target of tyrosine kinase inhibitors. Oncogene 30(7): 757$769,2011$.

10 Gadd SJ and Ashman LK: A murine monoclonal antibody specific for a cell-surface antigen expressed by a subgroup of human myeloid leukaemias. Leuk Res 9(11): 1329-1336, 1985.

11 Welker P, Schadendorf D, Artuc M, Grabbe J and Henz BM: Expression of scf splice variants in human melanocytes and melanoma cell lines: Potential prognostic implications. Br J Cancer 82(8): 1453-1458, 2000. 
12 Anderson DM, Williams DE, Tushinski R, Gimpel S, Eisenman J, Cannizzaro LA, Aronson M, Croce CM, Huebner K, Cosman $\mathrm{D}$ et al: Alternate splicing of mrnas encoding human mast cell growth factor and localization of the gene to chromosome 12q22-q24. Cell Growth Differ 2(8): 373-378, 1991.

13 Matsui Y, Zsebo KM and Hogan BL: Embryonic expression of a haematopoietic growth factor encoded by the sl locus and the ligand for c-kit. Nature 347(6294): 667-669, 1990.

14 Aqmasheh S, Shamsasanjan k, Akbarzadehlaleh P, Pashoutan Sarvar D and Timari H: Effects of mesenchymal stem cell derivatives on hematopoiesis and hematopoietic stem cells. Adv Pharm Bull 7(2): 165-177, 2017.

15 d'Auriol L, Mattei MG, Andre C and Galibert F: Localization of the human c-kit protooncogene on the q11-q12 region of chromosome 4. Hum Genet 78(4): 374-376, 1988.

16 Lennartsson J and Ronnstrand L: Stem cell factor receptor/c-kit: From basic science to clinical implications. Physiol Rev 92(4): 1619-1649, 2012.

17 Broudy VC, Lin NL, Buhring HJ, Komatsu N and Kavanagh TJ: Analysis of c-kit receptor dimerization by fluorescence resonance energy transfer. Blood 91(3): 898-906, 1998.

18 Ronnstrand L: Signal transduction via the stem cell factor receptor/c-kit. Cell Mol Life Sci 61(19-20): 2535-2548, 2004.

19 Abbaspour Babaei M, Kamalidehghan B, Saleem M, Huri HZ and Ahmadipour F: Receptor tyrosine kinase (c-kit) inhibitors: A potential therapeutic target in cancer cells. Drug Des Devel Ther 10: 2443-2459, 2016.

20 Ongkeko WM, Altuna X, Weisman RA and Wang-Rodriguez J: Expression of protein tyrosine kinases in head and neck squamous cell carcinomas. Am J Clin Pathol 124(1): 71-76, 2005.

21 Goldinger SM, Murer C, Stieger P and Dummer R: Targeted therapy in melanoma - the role of braf, ras and kit mutations. Eur J Cancer Suppl 11(2): 92-96, 2013.

22 Hersmus R, Stoop H, van de Geijn GJ, Eini R, Biermann K, Oosterhuis JW, Dhooge C, Schneider DT, Meijssen IC, Dinjens WN, Dubbink HJ, Drop SL and Looijenga LH: Prevalence of ckit mutations in gonadoblastoma and dysgerminomas of patients with disorders of sex development (dsd) and ovarian dysgerminomas. PLoS One 7(8): e43952, 2012.

23 Mayer EL and Krop IE: Advances in targeting src in the treatment of breast cancer and other solid malignancies. Clin Cancer Res 16(14): 3526-3532, 2010.

24 Wheeler DL, Iida M and Dunn EF: The role of src in solid tumors. Oncologist 14(7): 667-678, 2009.

25 Parsons SJ and Parsons JT: Src family kinases, key regulators of signal transduction. Oncogene 23(48): 7906-7909, 2004.

26 Kanda S, Miyata Y, Kanetake H and Smithgall TE: Non-receptor protein-tyrosine kinases as molecular targets for antiangiogenic therapy (review). Int J Mol Med 20(1): 113-121, 2007.

27 Bjorge JD, Jakymiw A and Fujita DJ: Selected glimpses into the activation and function of src kinase. Oncogene 19(49): 56205635, 2000.

28 Liu W, Yue F, Zheng M, Merlot A, Bae DH, Huang M, Lane D, Jansson P, Lui GY, Richardson V, Sahni S, Kalinowski D, Kovacevic $\mathrm{Z}$ and Richardson DR: The proto-oncogene c-src and its downstream signaling pathways are inhibited by the metastasis suppressor, ndrg1. Oncotarget 6(11): 8851-8874, 2015.

29 Tsai CJ and Nussinov R: The molecular basis of targeting protein kinases in cancer therapeutics. Semin Cancer Biol 23(4): 235-242, 2013.
30 Schmidt S and Gastl G: Zielgerichtete therapie: Tyrosinkinaseinhibitoren in der klinischen onkologie. ONKOLOGIE heute 14(3): 41-46, 2015.

31 Druker BJ, Guilhot F, O’Brien SG, Gathmann I, Kantarjian H, Gattermann N, Deininger MW, Silver RT, Goldman JM, Stone RM, Cervantes F, Hochhaus A, Powell BL, Gabrilove JL, Rousselot P, Reiffers J, Cornelissen JJ, Hughes T, Agis H, Fischer T, Verhoef G, Shepherd J, Saglio G, Gratwohl A, Nielsen JL, Radich JP, Simonsson B, Taylor K, Baccarani M, So C, Letvak L and Larson RA: Five-year follow-up of patients receiving imatinib for chronic myeloid leukemia. N Engl J Med 355(23): 2408-2417, 2006.

32 Veber DF, Johnson SR, Cheng HY, Smith BR, Ward KW and Kopple KD: Molecular properties that influence the oral bioavailability of drug candidates. J Med Chem 45(12): 26152623, 2002.

33 Blaszczak W, Barczak W, Wegner A, Golusinski W and Suchorska WM: Clinical value of monoclonal antibodies and tyrosine kinase inhibitors in the treatment of head and neck squamous cell carcinoma. Med Oncol 34(4): 60, 2017.

34 Machiels JP, Haddad RI, Fayette J, Licitra LF, Tahara M, Vermorken JB, Clement PM, Gauler T, Cupissol D, Grau JJ, Guigay J, Caponigro F, de Castro G, Jr., de Souza Viana L, Keilholz U, Del Campo JM, Cong XJ, Ehrnrooth E and Cohen EE: Afatinib versus methotrexate as second-line treatment in patients with recurrent or metastatic squamous-cell carcinoma of the head and neck progressing on or after platinum-based therapy (lux-head \& neck 1): An open-label, randomised phase 3 trial. Lancet Oncol 16(5): 583-594, 2015.

35 Ferris RL, Blumenschein G Jr., Fayette J, Guigay J, Colevas AD, Licitra L, Harrington K, Kasper S, Vokes EE, Even C, Worden F, Saba NF, Iglesias Docampo LC, Haddad R, Rordorf T, Kiyota N, Tahara M, Monga M, Lynch M, Geese WJ, Kopit J, Shaw JW and Gillison ML: Nivolumab for recurrent squamous-cell carcinoma of the head and neck. N Engl J Med 375(19): 1856-1867, 2016.

36 Sequist LV, Yang JC, Yamamoto N, O’Byrne K, Hirsh V, Mok T, Geater SL, Orlov S, Tsai CM, Boyer M, Su WC, Bennouna J, Kato T, Gorbunova V, Lee KH, Shah R, Massey D, Zazulina V, Shahidi M and Schuler M: Phase iii study of afatinib or cisplatin plus pemetrexed in patients with metastatic lung adenocarcinoma with egfr mutations. J Clin Oncol 31(27): 33273334, 2013.

37 Giaccone G and Wang Y: Strategies for overcoming resistance to egfr family tyrosine kinase inhibitors. Cancer treatment reviews 37(6): 456-464, 2011.

38 Yang JC, Wu YL, Schuler M, Sebastian M, Popat S, Yamamoto N, Zhou C, Hu CP, O’Byrne K, Feng J, Lu S, Huang Y, Geater SL, Lee KY, Tsai CM, Gorbunova V, Hirsh V, Bennouna J, Orlov S, Mok T, Boyer M, Su WC, Lee KH, Kato T, Massey D, Shahidi M, Zazulina V and Sequist LV: Afatinib versus cisplatin-based chemotherapy for egfr mutation-positive lung adenocarcinoma (luxlung 3 and lux-lung 6): Analysis of overall survival data from two randomised, phase 3 trials. Lancet Oncol 16(2): 141-151, 2015.

39 Soria JC, Felip E, Cobo M, Lu S, Syrigos K, Lee KH, Goker E, Georgoulias V, Li W, Isla D, Guclu SZ, Morabito A, Min YJ, Ardizzoni A, Gadgeel SM, Wang B, Chand VK and Goss GD: Afatinib versus erlotinib as second-line treatment of patients with advanced squamous cell carcinoma of the lung (lux-lung 8): An open-label randomised controlled phase 3 trial. Lancet Oncol 16(8): 897-907, 2015. 
40 le Coutre P, Schwarz M and Kim TD: New developments in tyrosine kinase inhibitor therapy for newly diagnosed chronic myeloid leukemia. Clin Cancer Res 16(6): 1771-1780, 2010.

41 Pérez-Soler R, Chachoua A, Hammond LA, Rowinsky EK, Huberman M, Karp D, Rigas J, Clark GM, Santabárbara P and Bonomi P: Determinants of tumor response and survival with erlotinib in patients with non-small-cell lung cancer. J Clin Oncol 22(16): 3238-3247, 2004.

42 Lynch TJ, Bell DW, Sordella R, Gurubhagavatula S, Okimoto RA, Brannigan BW, Harris PL, Haserlat SM, Supko JG, Haluska FG, Louis DN, Christiani DC, Settleman J and Haber DA: Activating mutations in the epidermal growth factor receptor underlying responsiveness of non-small-cell lung cancer to gefitinib. N Engl J Med 350(21): 2129-2139, 2004.

43 Manley PW, Drueckes P, Fendrich G, Furet P, Liebetanz J, Martiny-Baron G, Mestan J, Trappe J, Wartmann M and Fabbro D: Extended kinase profile and properties of the protein kinase inhibitor nilotinib. Biochim Biophys Acta 1804(3): 445-453, 2010.

44 Weisberg E, Manley P, Mestan J, Cowan-Jacob S, Ray A and Griffin JD: Amn107 (nilotinib): A novel and selective inhibitor of bcr-abl. Brit J Cancer 94(12): 1765-1769, 2006.

45 de Melo Maia B, Lavorato-Rocha AM, Rodrigues IS, Baiocchi G, Cestari FM, Stiepcich MM, Chinen LT, Carvalho KC, Soares FA and Rocha RM: Prognostic significance of c-kit in vulvar cancer: Bringing this molecular marker from bench to bedside. J Transl Med 10: 150, 2012.

46 Umbreit C, Aderhold C, Faber A, Sommer JU, Sauter A, Hofheinz RD, Stern-Strater J, Hoermann K and Schultz JD: Unexpected alteration of beta-catenin and c-kit expression by 5fu and docetaxel in p16-positive squamous cell carcinoma compared to hpv-negative hnscc cells in vitro. Anticancer Res 33(6): 2457-2465, 2013.

47 Geletu M, Guy S and Raptis L: Effects of src and stat3 upon gap junctional, intercellular communication in lung cancer lines. Anticancer Res 33(10): 4401-4410, 2013.

48 Kramer B, Hock C, Birk R, Sauter A, Stuck BA, Hormann K, Schultz JD and Aderhold C: Targeted therapies in hpv-positive and -negative hnscc - alteration of egfr and vegfr-2 expression in vitro. Anticancer Res 36(6): 2799-2807, 2016.

49 Aderhold C, Faber A, Grobschmidt GM, Chakraborty A, Bockmayer A, Umbreit C, Birk R, Stern-Straeter J, Hormann K and Schultz JD: Small molecule-based chemotherapeutic approach in p16-positive and -negative hnscc in vitro. Anticancer Res 33(12): 5385-5393, 2013.

50 Kramer B, Hock C, Schultz JD, Lammert A, Kuhlin B, Birk R, Hormann $\mathrm{K}$ and Aderhold C: Impact of small molecules on betacatenin and e-cadherin expression in hpv16-positive and -negative squamous cell carcinomas. Anticancer Res 37(6): 2845-2852, 2017.
51 Kramer B, Schultz JD, Hock C, Sauter A, Stuck BA, Hormann K, Birk R and Aderhold C: Effect of selective small molecule inhibitors on mmp-9 and vegfr- 1 expression in p16-positive and -negative squamous cell carcinoma. Oncol Lett 13(5): 32693276, 2017.

52 Tencer L, Burgermeister E, Ebert MP and Liscovitch M: Rosiglitazone induces caveolin-1 by ppargamma-dependent and ppre-independent mechanisms: The role of egf receptor signaling and its effect on cancer cell drug resistance. Anticancer Res 28(2A): 895-906, 2008.

53 Stabile LP, He G, Lui VW, Thomas S, Henry C, Gubish CT, Joyce S, Quesnelle KM, Siegfried JM and Grandis JR: C-src activation mediates erlotinib resistance in head and neck cancer by stimulating c-met. Clin Cancer Res 19(2): 380-392, 2013.

54 Sequist LV, Bell DW, Lynch TJ and Haber DA: Molecular predictors of response to epidermal growth factor receptor antagonists in non-small-cell lung cancer. J Clin Oncol 25(5): 587-595, 2007.

55 Wheeler DL, Iida M, Kruser TJ, Nechrebecki MM, Dunn EF, Armstrong EA, Huang S and Harari PM: Epidermal growth factor receptor cooperates with src family kinases in acquired resistance to cetuximab. Cancer Biol Ther 8(8): 696-703, 2009.

56 Thibault B and Jean-Claude B: Dasatinib + gefitinib, a non platinum-based combination with enhanced growth inhibitory, anti-migratory and anti-invasive potency against human ovarian cancer cells. J Ovarian Res 10(1): 31, 2017.

57 Lin YC, Wu MH, Wei TT, Chuang SH, Chen KF, Cheng AL and Chen CC: Degradation of epidermal growth factor receptor mediates dasatinib-induced apoptosis in head and neck squamous cell carcinoma cells. Neoplasia 14(6): 463-475, 2012.

58 Dias JD, Guse K, Nokisalmi P, Eriksson M, Chen DT, Diaconu I, Tenhunen M, Liikanen I, Grenman R, Savontaus M, Pesonen S, Cerullo V and Hemminki A: Multimodal approach using oncolytic adenovirus, cetuximab, chemotherapy and radiotherapy in hnscc low passage tumour cell cultures. Eur J Cancer 46(3): 625-635, 2010.

59 Rieke DT, Klinghammer K and Keilholz U: Targeted therapy of head and neck cancer. Oncol Res Treat 39(12): 780-786, 2016.

Received March 15, 2018

Revised March 31, 2018

Accepted April 2, 2018 